E-ISSN : 2549-6581

OPEN ACCESS

DOI: 10.21776/ub.JOIM.2019.003.02.3

Journal of Issues in Midwifer

Artikel Hasil Penelitian

Diterima : 3 Juli 2018

Direview : 2 Juli 2019

Dimuat : Agustus 2019 - November 2019

\title{
Pengaruh Konsumsi Kacang Mente (Anacardium occidentale) Sangrai Pada Penurunan Skala Nyeri Dismenore Primer Siswi SMA Negeri 1 Lawang Periode November-Desember 2017
}

\author{
Intan Indah Lestari ${ }^{1 *}$, Dewi Ariani ${ }^{2}$, Inggita Kusumastuty ${ }^{3}$ \\ ${ }^{1 *}$ Program Studi S1 Kebidanan Fakultas Kedokteran Universitas Brawijaya, Email: \\ intanorlestari@gmail.com, Tlp: 08990898404 \\ 2 Program Studi S1 Kebidanan Fakultas Kedokteran Universitas Brawijaya \\ ${ }^{3}$ Program Studi Ilmu Gizi Fakultas Kedokteran Universitas Brawijaya
}

\begin{abstract}
Primary dysmenorrhea is painful menstrual cramps without any evident pelvic pathology and it happened more than 50\% of menstrual period females and causes significant disruption in quality of life. Pain in primary dismenorrhea and other systemic symptoms caused by high levels of prostaglandins. Primary dismenorrhea can be treated by pharmacological and nonpharmacological therapy. Cashew nut consumption is one of the nonpharmacological therapy that can reduce the pain intensity of primary dismenorrhea because it contains high magnesium. This study aim to determine the effect of cashew nut consumption (Anacardium occidetale) to reduce the pain intensity of primary dismenorrhea in students of SMAN 1 Lawang. The design of this research used was true experiment with pre test and post test with control group design. The samples were used in this study are 21 people divided into three groups. This study was conducted during one menstrual cycle. The results showed that there was a difference of decrease pain intensity between three group using One way ANOVA test with significance number of $0.000(p<0.05)$. From this research result the best dose to reduce pain intensity of primary dismenorrhea is $68 \mathrm{gr}$ cashew nut that contain $300 \mathrm{mg}$ of magnesium. Therefore this study suggest that teenagers can use cashew nut consumption as a choice to reduce pain in primary dismenorrhea.
\end{abstract}

Keywords: Primary Dysmenorrhea, Cashew nut, Magnesium

\begin{abstract}
ABSTRAK
Dismenore primer merupakan nyeri kram menstruasi tanpa adanya kelainan pada panggul dan terjadi lebih dari $50 \%$ pada wanita yang mengalami mentruasi dan mengganggu kualitas hidup seseorang. Nyeri pada dismenore primer dan gejala sistemik lain yang muncul disebabkan oleh tingginya kadar prostaglandin. Dismenore primer dapat diobati dengan terapi secara farmakologis dan nonfarmakologis. Konsumsi kacang mente adalah salah satu terapi nonfarmakologis yang dapat menurunkan intensitas nyeri dismenore primer karena mengandung magnesium yang tinggi. Tujuan dari penelitian ini adalah untuk mengetahui adanya pengaruh konsumsi kacang mente terhadap penurunan skala nyeri dismenore primer pada siswi SMAN 1 Lawang. Desain penelitian menggunakan desain eksperimental murni dengan pre test-post test with control group. Sampel dalam penelitian ini berjumlah 21 orang yang dibagi menjadi tiga kelompok yaitu kelompok eksperimental I, kelompok eksperimental II, dan kelompok kontrol. Teknik
\end{abstract}


pengambilan sampel dilakukan secara simple random sampling. Penelitian ini dilakukan selama satu siklus menstruasi. Hasil penelitian menunjukkan bahwa ada perbedaan penurunan intensitas nyeri dismenore primer pada ketiga kelompok menggunakan uji One way ANOVA dengan angka signifikansi $0.000(p<0.05)$. Dari hasil penelitian ini didapatkan dosis terbaik untuk menurunkan nyeri dismenore primer adalah 68 gram kacang mente yang mengandung $300 \mathrm{mg}$ magnesium. Maka dari itu disarankan kepada remaja putri untuk dapat menjadikan konsumsi kacang mente sebagai pilihan untuk menurunkan nyeri dismenore primer.

Kata kunci: Dismenore Primer, Kacang Mente, Magnesium

*Korespondensi: Intan Indah Lestari Surel: intanorlestari@gmail.com

\section{PENDAHULUAN}

Dismenore primer adalah kram menstruasi umum yang terjadi berulang dan bukan karena penyakit organ reproduksi lainnya. Nyeri biasanya dimulai 1 atau 2 hari sebelum, atau ketika perdarahan menstruasi dimulai, dan dirasakan di perut bagian bawah, punggung atau paha. ${ }^{1,2}$ Nyeri yang dirasakan dapat berupa nyeri ringan hingga berat, yang berlangsung selama 12 hingga 72 jam, dan dapat disertai dengan mual, muntah, merasa lelah, dan diare. Dismenore terjadi karena tingginya kadar prostaglandin yang mencapai hingga $3 x$ lipat pada jaringan uterus sehingga menyebabkan kontraksi uterus yang berlebih dan menimbulkan rasa nyeri. $^{3}$

Dismenore primer dapat mempengaruhi hingga $50 \%$ dari semua wanita yang memiliki periode menstruasi, dan $15 \%$ dari wanita ini akan memiliki tingkat rasa sakit yang mengganggu aktivitas seharihari mereka. Dismenore tidak hanya masalah reproduksi bagi seorang wanita, tetapi juga berdampak pada kualitas hidup dan menurunkan produktivitas wanita secara umum. Prevalensi dismenore diperkirakan hingga $90 \%$ pada remaja, dan pada kenyataannya, hal terebut dapat mengganggu kehidupan, baik secara fisik maupun psikologis. ${ }^{4,5}$ Dalam studi epidomiologi pada populasi remaja (usia 12-17 th) di
Amerika serikat, prevalensi dismenore sebesar 59,7\%. Dari para remaja yang mengeluhkan dismenore, $12 \%$ tergolong nyeri berat, 37\% nyeri intensitas sedang, dan $49 \%$ nyeri dengan intensitas ringan. ${ }^{6}$ Pada penelitian yang dilakukan di Universitas Turki menunjukkan sebanyak $87,8 \%$ mahasiswinya mengalami dismenore. Penelitian lain yang dilakukan di Nigeria University sebesar 84,9\% mahasiwi merasakan dismenore. ${ }^{7}$

$$
\text { Penanganan dismenore }
$$

secara farmakologis dengan Nonsteroidal anti-inflammatory drugs (NSAIDs) adalah terapi utama yang digunakan untuk penderita dismenore primer. Berdasarkan data evidence-based mendukung keefektifan dari ibuprofen, naproxen, mefenamic acid, dan aspirin sebagai pereda nyeri dismenore. Akan tetapi, obat-obat tersebut memiliki efek samping berupa gangguan pada sistem pencernaan seperti mual, dyspepsia, dan muntah. Dan juga, beberapa wanita kontraindikasi pada obat-obatan tersebut.8,9,10 Oleh karena itu, peneliti ingin mencari alternatif atau pengobatan yang lain seperti pengobatan secara herbal atau pengobatan terkait dengan pola makan.

Zat gizi yang dapat membantu meringankan dismenore yaitu kalsium, magnesium, serta Vitamin A, E, B6, dan C. ${ }^{11}$ Kacang 
mente memiliki kandungan magnesium yang cukup tinggi. Kandungan magnesium pada kacang mente yang telah di sangrai berada pada urutan ketiga setelah ikan halibut dan kacang almond. Kandungan magnesium pada kacang mente sangrai sejumlah 75 $\mathrm{mg} / 28,35$ gram kacang mete sangrai. ${ }^{12}$ Dalam uji analisis yang dilakukan oleh peneliti pada laboratorium kimia Universitas Brawijaya, kandungan magnesium kacang mente sangrai sebanyak 4418,69 ppm. Dari hasil tersebut dapat diartikan bahwa dalam $100 \mathrm{gr}$ kacang mente mengandung 441,86 mg magnesium. Magnesium merupakan salah satu mineral yang bertanggung jawab dalam mengatur kontraksi otot. Sehingga kandungan magnesium pada kacang mente sangrai dapat berfungsi memperbesar pembuluh darah sehingga mencegah kejang otot dan dinding pembuluh darah sehingga dapat meringankan dismenore. ${ }^{13}$

Produksi kacang mente di Indonesia bisa dikatakan cukup besar karena Indonesia merupakan salah satu negara pengasil kacang mente terbesar didunia selain Tanzania, India, Srilanka, Thailand dan Malaysia. Pada tahun 2015, dengan luas area sebesar 550.956 ha, Indonesia mampu menghasilkan kacang mente sebanyak 115.715 ton pada tahun tersebut. Dan Indonesia merupakan negara yang aktif melakukan ekspor ke berbagai negara seperti Jepang, Hongkong, Singapura, Vietnam, Korea, dan beberapa negara lainnya. ${ }^{14}$

Berdasarkan data studi pendahuluan di SMAN 1 Lawang pada bulan Juli 2017, pada siswi SMAN 1 Lawang kelas XI IPA 3 dan XI IPA 4 dari 46 siswi terdapat 23 siswi yang mengalami dismenore. Dismenore yang dirasakan oleh siswi tersebut terjadi sebelum atau segera setelah dimulainya menstruasi.

Berdasarkan paparan di atas, peneliti tertarik untuk meneliti pengaruh pemberian kacang mente sangrai terhadap penurunan intensitas nyeri dismenore primer. Selain cara pengkonsumsian yang mudah, kacang mente dapat dengan mudah diperoleh di Indonesia karena kacang mente merupakan produk lokal Indonesia.

\section{METODE PENELITIAN Rancangan/Desain Penelitian}

Penelitian ini menggunakan desain eksperimental murni (True Eksperimental Design) dengan menggunakan rancangan The Randomized Pre Test-Post Test Control Group Design.

\section{Sumber Data}

Data pada penelitian ini diperoleh dari hasil pengisian lembar NRS (Numerical Rating Scale) sebelum diberikan perlakuan (yaitu dalam rentang waktu $0-30$ menit saat rasa nyeri dismenore pertama kali dirasakan) dan pengisian lembar NRS 14 jam setelah diberikan perlakuan (dalam 1 siklus menstruasi).

\section{Sasaran Penelitian (Populasi/Sampel/Subjek Penelitian)}

Penelitian ini dilakukan pada siswi kelas $X$ dan XI SMAN 1 Lawang tahun ajaran 2017/2018 yang berusia 15-17 tahun dan mengalami dismenore primer yang sesuai dengan kriteria inklusi dan 
eksklusi. Kemudian membagi reponden menjadi 3 kelompok perlakuan dengan menggunakan teknik simple random sampling. Jumlah siswi yang menjadi sampel sebanyak 21 orang yang dibagi menjadi tiga kelompok perlakuan dengan jumlah responden pada masing-masing kelompok adalah 7 orang. Teknik

\section{Pengembangan Instrumen dan Teknik Pengumpulan Data}

Intrumen yang digunakan

dalam penelitian ini adalah sebagai berikut:

1. Kuesioner

karakteristik responden, informed consent, lembar penjelasan mengikuti penelitian, dan lembar skrinning responden

2. Kacang mente sangrai yang didapatkan oleh peneliti dari toko oleh-oleh "LaiLai" dengan merk dagang "X", netto 197 gram perkemasan yang sudah berBPOM yang selanjutnya akan di bagi menjadi 3 bagian menggunakan timbangan digital dengan masing masing bagian sebanyak 27 gram kacang mente untuk kelompok eksperimental I dan 23 gram kacang mente untuk kelompok eksperimental II. Pada kelompok kontrol, responden tetap diberi kacang mente sebanyak 68 gram untuk memenuhi asas keadilan dalam penelitian akan tetapi kacang mente tersebut hanya boleh dikonsumsi setelah penelitian berakhir.

3. Lembar kuesioner intensitas nyeri NRS yang disediakan dalam satu garis horizontal yang terdapat skala numeral dari angka 0-10.

4. Wadah kacang mente dan label.
5. Timbangan bahan makanan digital untuk menimbang kacang mente.

6. Timbangan berat badan dan pengukur tinggi badan.

Prosedur pengumpulan data dengan mencari persetujuan responden yaitu siswi SMAN 1 Lawang yang mengalami dismenore primer yang telah terpilih menjadi subjek penelitian, lalu melakukan observasi sebelum dilakukan perlakuan berupa konsumsi kacang mente dan meminta responden untuk mengisi lembar kuesioner intensitas nyeri Numerical Rating Score (NRS) pada kelompok eksperimental I, II, dan kelompok kontrol. Setelah mengisi lembar kuesioner NRS pre-test, selanjutnya memberikan perlakuan pada kelompok eksperimental I dan II berupa konsumsi kacang mente 27 gram sebanyak 3 wadah untuk kelompok eksperimental I dan untuk kelompok eksperimental II 23 gram sebanyak 3 wadah dengan aturan mengonsumsi yakni setiap 4 jam sekali dalam 12 jam selama satu hari sakit dirasakan. Setelah kelompok eksperimental I dan kelompok eksperimental II diberikan perlakuan selama 12 jam selanjutnya ketiga kelompok diminta peneliti untuk mengisi lembar kuesioner intensitas nyeri NRS pasca pemberian perlakuan.

\section{Teknik Analisis Data}

Setelah

dilakukan pengambilan dan pengumpulan data, dilakukan uji normalitas menggunakan uji Shapiro wilk dikarenakan jumlah sampel kurang dari 50 ( $p>0.05)$. Analisis deskriptif digunakan untuk melihat gambaran umum karakteristik responden. Selanjutnya dilakukan Uji statistik One Way Anova untuk mengetahui 
perbedaan penurunan intensitas nyeri pada ketiga kelompok penelitian. Dalam uji statistik ini, konsumsi kacang mente sangrai dapat dikatakan mempengaruhi perubahan intensitas nyeri dismenore primer apabila $p \leq 0,05$. Pada proses pengolahan data, peneliti menggunakan software
SPSS Version 19 for windows sebagai alat bantu untuk mengolah data.

\section{Ethical Clearance}

Surat Keterangan Laik Etik oleh Komisi Etik Penelitian Kesehatan FKUB No. 348/EC/KEPK-S1-KB/10/2017.

\section{HASIL PENELITIAN}

Karakteristik Responden

Tabel 1. Karakteristik Responden

\begin{tabular}{cccc}
\hline \multirow{2}{*}{ Karakteristik } & \multirow{2}{*}{ Kategori } & \multicolumn{2}{c}{ Jumlah } \\
\cline { 3 - 4 } & U & $\%$ \\
\hline \multirow{2}{*}{ Usia } & 15 tahun & 5 & 23,8 \\
& 16 tahun & 11 & 52,4 \\
& 17 tahun & 5 & 23,8 \\
\hline \multirow{2}{*}{ Status gizi } & Underweight & - & - \\
& Normal & 21 & 100 \\
& Overweight & - & - \\
\hline \multirow{3}{*}{ Penanganan saat nyeri } & Dibiarkan & 16 & 76,2 \\
& Tidur/istirahat & 4 & 19 \\
& Minum air puth & 1 & 4,8 \\
\hline
\end{tabular}

Responden dalam penelitian ini berusia 15-17 tahun dan sebagian besar diantaranya berusia 16 tahun yaitu sebanyak 11 responden $(52,4 \%)$. Status gizi pada seluruh responden dalam kategori normal yaitu sebanyak 21 responden (100\%) yang artinya seluruh responden tidak ada yang mengalami underweight ataupun overweight.
Sedangkan karakteristik penanganan saat nyeri pada responden sebagian besar menanganinya hanya dengan dibiarkan saja yaitu sebanyak 16 responden $(76,2 \%)$ dan hanya 1 responden $\quad(4,8 \%) \quad$ yang menanganinya dengan cara mengonsumsi air putih. 


\section{Pengaruh Konsumsi Kacang Mente (Anacardium occidentale) Terhadap Perubahan Skala Nyeri Dismenore Primer}

Tabel 2. Intensitas Nyeri Dismenore Primer Sebelum dan Sesudah diberikan Perlakuan

\begin{tabular}{|c|c|c|c|c|c|c|c|}
\hline \multirow{2}{*}{$\begin{array}{l}\text { Kelompok } \\
\text { perlakuan }\end{array}$} & \multirow[t]{2}{*}{ Intensitas nyeri } & \multicolumn{3}{|c|}{$\begin{array}{c}\text { Sebelum diberikan } \\
\text { perlakuan }\end{array}$} & \multicolumn{3}{|c|}{$\begin{array}{l}\text { Setelah diberikan } \\
\text { perlakuan }\end{array}$} \\
\hline & & $\mathbf{n}$ & $\%$ & Rata-rata & $\mathbf{n}$ & $\%$ & Rata-rata \\
\hline \multirow{4}{*}{$\begin{array}{l}\text { Eksperimental I } \\
\text { (82 gram) }\end{array}$} & Tidak nyeri & - & - & \multirow{4}{*}{4,7} & 5 & 71,4 & \multirow{4}{*}{0,6} \\
\hline & Nyeri ringan & - & - & & 2 & 28,6 & \\
\hline & Nyeri sedang & 7 & 100 & & - & - & \\
\hline & Nyeri berat & - & - & & - & - & \\
\hline \multirow{4}{*}{$\begin{array}{l}\text { Eksperimental II } \\
\text { (68 gram) }\end{array}$} & Tidak nyeri & - & - & \multirow{4}{*}{5,1} & - & - & \multirow{4}{*}{2,4} \\
\hline & Nyeri ringan & - & - & & 6 & 85,7 & \\
\hline & Nyeri sedang & 7 & 100 & & 1 & 14,3 & \\
\hline & Nyeri berat & - & - & & - & - & \\
\hline \multirow{4}{*}{ Kontrol } & Tidak nyeri & - & - & \multirow{4}{*}{4,3} & - & - & \multirow{4}{*}{4,9} \\
\hline & Nyeri ringan & 2 & 28,6 & & 2 & 28,6 & \\
\hline & Nyeri sedang & 5 & 71,4 & & 4 & 57,1 & \\
\hline & Nyeri berat & - & - & & 1 & 14,3 & \\
\hline
\end{tabular}

*Keterangan:

- Kelompok eksperimental I yang selanjutnya akan disingkat dengan P1: pemberian kacang mente sebanyak 82 gram

- Kelompok eksperimental II yang selanjutnya akan disingkat dengan P2: pemberian kacang mente sebanyak 68 gram

Pada tabel 2 dapat dilihat bahwa sebelum diberikan perlakuan seluruh responden pada P1 mengalami nyeri sedang yaitu sebanyak 7 responden (100\%) dengan rata-rata intensitas nyeri dismenore primer sebesar 4,7. Setelah diberikan perlakuan, ratarata intensitas nyeri yang dirasakan oleh responden pada P1 adalah sebesar 0,6. Dari ke 7 responden pada P1 sebagian besar responden yaitu 5 responden $(71,4 \%)$ tidak merasakan nyeri dismenore primer. Sehingga dapat diketahui delta nyeri pada P1 berdasarkan intensitas nyeri pre dan post perlakuan adalah sebesar 4,14.

Pada P2, dengan rata-rata intensitas nyeri dismenore primer sebesar 5,1 seluruh responden sebelum diberikan perlakuan mengalami nyeri sedang yaitu sebanyak 7 responden (100\%). Setelah diberikan perlakuan, ratarata intensitas nyeri pada P2 adalah sebesar 2,4 dan dari 7 responden, 6 responden $(85,7 \%)$ mengalami nyeri ringan dan 1 responden (14,3\%) mengalami nyeri sedang. Sehingga, pada P2 delta nyerinya sebesar 2,71 .

Pada kelompok kontrol sebelum diberikan perlakuan sebanyak 5 responden $(71,4 \%)$ mengalami nyeri sedang dan ratarata intensitas nyeri seluruh responden pada kelompok kontrol adalah sebesar 4,3. Setelah 12 jam masa penelitian, rata-rata intensitas nyerinya menjadi 4,9 dan dari 7 responden, 4 responden $(57,1 \%)$ mengalami nyeri sedang, 2 responden $(28,6 \%)$ mengalami nyeri ringan dan 1 responden (14,3\%) 
mengalami nyeri berat. Sehingga delta nyeri pada kelompok kontrol adalah sebesar $-0,57$.

Dari penjabaran tabel diatas dapat diketahui bahwa sebagian besar responden pada P1 dan P2 mengalami penurunan intensitas nyeri dismenore primer setelah diberikan perlakuan. Akan tetapi, kelompok yang memiliki delta nyeri terbesar adalah pada P1. Sedangkan pada kelompok kontrol, sebagian besar responden mengalami intensitas nyeri dismenore primer yang tetap setelah 12 jam dalam masa penelitian bahkan terdapat responden yang mengalami peningkatan intensitas nyeri dismenore primer. Dan pada kelompok kontrol, delta nyeri menunjukkan angka negatif (-) yang artinya responden pada kelompok ini cenderung mengalami peningkatan intensitas nyeri dismenore primer.

\section{Analisis Data}

Pada penelitian ini uji normalitas data menggunakan Shapiro Wilk menunjukkan angka signifikansi 0,113 yang artinya angka tersebut dapat dikatakan terdistribusi normal. Pada uji homogenitas variasi diperoleh angka signifikansi sebesar 0,403 yang artinya adalah data telah memiliki varian yang homogen $(p>0,05)$ sehingga dapat dilanjutkan dengan uji one way ANOVA. Uji one way ANOVA menunjukkan hasil signifikansi 0,000 yang dapat diartian bahwa terdapat perbedaan yang bermakna pada semua kelompok. Sehingga dapat disimpulkan bahwa konsumsi kacang mente dengan dosis yang telah ditetapkan dapat menurunkan intensitas nyeri dismenore primer pada remaja putri yang mengalami dismenore. Berikut adalah nilai mean pada uji one way ANOVA:

\section{Tabel 3. Perbedaan Intensitas Nyeri Dismenore Primer Pada Kelompok Eksperimental Dan Kelompok Kontrol Setelah Diberikan Perlakuan Dengan Uji One Way ANOVA}

\begin{tabular}{lcc}
\hline Tindakan & N & $\begin{array}{c}\text { Mean (Delta } \\
\text { Nyeri) }\end{array}$ \\
\hline P1 $(82 \mathrm{gr})$ & 7 & 4,14 \\
P2 $(68 \mathrm{gr})$ & 7 & 2,71 \\
Kontrol & 7 & $-0,57$ \\
\hline Total & 21 & 2,343 \\
\hline Keterangan \\
• P1: pemberian kacang mente sebanyak \\
82 gram \\
- P2: pemberian kacang mente sebanyak \\
68 gram
\end{tabular}

Berdasarkan tabel 3 dapat dilihat bahwa nilai mean delta nyeri didapatkan angka 4,14 pada P1, angka 2,71 pada dosis P2, serta angka mean delta nyeri $-0,57$ pada kelompok kontrol. Pengukuran nilai mean ini didapatkan dari data angka besar penurunan intensitas nyeri dismenore primer antara sebelum dan sesudah diberikan perlakuan. Semakin tinggi nilai mean maka dapat diartikan semakin besar pula pengaruh pemberian kacang mente terhadap penurunan intensitas nyeri dismenore primer. Dari tabel tersebut juga dapat dilihat bahwa dengan pemberian kacang mente pada kelompok eksperimental I sebanyak 82 gram dapat menurunkan intensitas nyeri dismenore primer paling besar dibandingkan dengan kelompok perlakuan yang lain. 
Tabel 4. Hasil Uji Post Hoc

\begin{tabular}{lcc}
\hline Kelompok & Signifikansi & Keterangan \\
\hline P1 $(82$ & \multirow{2}{*}{0,000} & Signifikan \\
gram $)-$ & 0,000 \\
Kontrol & & \\
P2 $(68$ & & \\
gram $)-$ & 0,000 & Signifikan \\
Kontrol & & \\
P1 (82 & & Tidak \\
gram $)-$ & 0,109 & Signifikan \\
P2 $(68$ & & \\
gram $)$ & & \\
\hline Keterangan & & \\
- P1: pemberian kacang mente sebanyak \\
82 gr \\
- P2: pemberian kacang mente sebanyak \\
68 gr
\end{tabular}

Hasil uji Post Hoc pada tabel 4 dapat diketahui bahwa terdapat perbedaan bermakna antara $\mathrm{P} 1$ terhadap kelompok kontrol dengan

\section{PEMBAHASAN}

\section{Karakteristik responden}

Berdasarkan tabel 1 menunjukkan hasil penelitian yang dilakukan pada siswi di SMA Negeri 1 Lawang didapatkan responden yang mengalami dismenore primer terjadi pada usia 15-17 tahun. Sebagian besar responden yang mengalami dismenore primer berusia 16 tahun sebanyak 11 resonden $(52,4 \%)$, sedangkan yang berusia 15 tahun dan 17 tahun masing-masing sebanyak 5 responden $(23,8 \%)$. Penelitian yang dilakukan oleh Gagua (2012) juga menunjukkan bahwa dari 431 responden yang masuk dalam penelitian, rata-rata usia responden yang mengalami dismenore primer terdapat pada usia $16 \pm 1,39$ tahun. ${ }^{15}$ Penelitian yang dilakukan oleh Mufaridah dan Sumaryani (2014) juga menunjukkan bahwa usia responden yang paling banyak mengalami dismenore primer adalah signifikansi $p=0,0001$. Dan antara P2 terhadap kelompok kontrol terdapat perbedaan bermakna dengan signifikansi $p=0,000$. Namun antara $\mathrm{P} 1$ dan $\mathrm{P} 2$ tidak terdapat perbedaan bermakna dengan signifikansi $p=0,109$. Dari hasil uji Post Hoc ini dapat disimpulkan bahwa dengan pemberian kacang mente sebanyak 68 gram pada kelompok eksperimental II sudah memiliki perbedaan yang bermakna terhadap penurunan intensitas nyeri dismenore primer. Sehingga dengan penambahan dosis menjadi 82 gram pada kelompok eksperimental I kurang memiliki perbedaan yang bermakna terhadap penurunan intensitas nyeri dismenore primer dibandingkan dengan kelompok eksperimental I.

usia 16 tahun sebanyak $70 \% .{ }^{16} \mathrm{Hal}$ ini terjadi karena pada remaja usia 14-18 tahun terjadi perkembangan organ-organ reproduksi dan perubahan hormonal yang signifikan dan pada usia tersebut terjadi optimaslisasi fungsi saraf rahim sehingga sekresi prostaglandin meningkat dan menimbulkan rasa nyeri. Selain itu juga dikarenakan pada usia tersebut hormone progesterone, estrogen, Luteining Hormone (LH) dan Folicel Stimulating Hormone (FSH) yang dimiliki masih belum stabil (Baziad, 2003). ${ }^{17}$

Pada karakteristik BMI responden, seluruh responden dalam penelitian ini memliki BMI normal yang artinya seluruh responden tidak ada yang mengalami overweight maupun underweight. Dalam penelitian ini, peneliti mengekslusi responden yang mengalami overweight maupun underweight untuk 
meminimalisir terjadinya bias pada penelitian ini dikarenakan status gizi overweight maupun underweight dapat mempengaruhi kejadian dismenorea. Hal ini dikarenakan pada seorang yang mengalami overweight cenderung mengalami defisiensi magnesium (Rude, 2012). ${ }^{18}$

Penanganan nyeri yang dilakukan responden berdasarkan tabel 5.1 sebagian besar responden hanya membiarkan nyeri dismenore primer yang dialaminya yaitu sebanyak 16 responden $(76,2 \%)$ sedangkan 4 responden (19\%) menangani nyeri dengan cara tidur atau istirahat dan 1 responden $(4,8 \%)$ menangani nyeri dengan cara minum air putih. Dari hasil penelitian ini dapat dilihat bahwa sebagian besar responden tidak mengurangi nyeri dismenore dengan cara meminum obat pereda nyeri seperti golongan NSAID. Hal ini dikarenakan responden takut akan dampak ketergantungan atau efek samping yang timbul jika mengonsumsi obat-obatan tersebut. Hal ini sesuai dengan pernyataan Mirabi et al (2011) yang menyatakan bahwa NSAID memiliki berbagai efek samping seperti mual, muntah, pusing, petechiae, hiperkalemia, edema perifer, dan perdarahan pada lambung. ${ }^{19}$ Penelitian yang dilakukan oleh Gagua (2012) juga menunjukkan bahwa dari 431 responden yang masuk dalam penelitian ini, sebesar 49,28\% responden hanya membiarkan nyeri dismenore primer yang dirasakannya, sedangkan hampir separuh responden yaitu sebesar $50,72 \%$ melakukan terapi terhadap nyeri dismenore yang dirasakannya, yaitu $17,69 \%$ menggunakannya untuk istirahat, $\quad 13,08 \%$ menggunakannya untuk mengerjakan pekerjaan lain, 14,23\% memilih untuk berbaring dengan posisi horizontal, 4,23\% tidak spesifik dan hanya 9,82\% responden yang mengurangi nyeri dismenorenya dengan cara mengonsumsi obat pereda nyeri golongan NSAID's. Hal ini menunjukkan bahwa meskipun tingginya persentase remaja putri yang mengalami dismenore primer tiap bulannya, pada penelitian ini menekankan bahwa sebagian besar remaja putri tidak mencari pengobatan medis dengan mengonsumsi NSAID's yang telah terbukti keefektifitasnnya dalam meredakan nyeri dismenore primer. ${ }^{15}$

\section{Intensitas Nyeri Dismenore Primer Responden Sebelum Diberikan Perlakuan}

Berdasarkan tabel 2 didapatkan hasil penelitian bahwa sebagian besar responden dalam penelitian ini sebelum diberikan perlakuan mengalami intensitas nyeri sedang sejumlah 19 responden $(90,5 \%)$ sedangkan 2 responden $(9,5 \%)$ mengalami nyeri ringan. Hal ini sejalan dengan penelitian yang dilakukan oleh Ortiz (2010), dari 961 responden yang terlibat dalam penelitian ini, sebanyak $36,1 \%$ melaporkan mengalami nyeri ringan, $43,8 \%$ mengalami nyeri sedang, dan $20,1 \%$ mengalami nyeri berat. ${ }^{20} \mathrm{Hal}$ serupa juga ditunjukkan oleh penelitian yang dilakukan oleh Nahid et al., (2009), dari 180 responden 65\% mengalami nyeri sedang, 18,9\% mengalami nyeri ringan dan $16,1 \%$ mengalami nyeri berat. Hasil penelitian ini menunjukkan tingkat nyeri dismenore primer yang 
bervariasi pada masing-masing responden karena ambang batas nyeri yang berbeda pada tiap responden. ${ }^{21} \mathrm{Hal}$ ini sesuai dengan pernyataan yang disampaikan oleh Tamsuri (2007), bahwa beberapa faktor seperti jenis kelamin, usia, dukungan keluarga/sosial, kultur/budaya, dan koping masingmasing individu dalam merasakan nyeri dapat memengaruhi perbedaan nyeri yang dirasakan individu. ${ }^{22}$

\section{Intensitas Nyeri Dismenore Primer Responden Setelah Diberikan Perlakuan}

Hasil penelitian yang telah dilakukan pada siswi di SMAN 1 Lawang menunjukkan adanya pengaruh konsumsi kacang mente terhadap penurunan intensitas nyeri dismenore primer dibuktikan dengan angka signifikansi pada uji One Way ANOVA adalah $p=0,000 \quad(p<0,05)$. Dosis kacang mente sebesar 82 gram yang diberikan sebanyak 27 gram setiap 4 jam sekali selama 12 jam merupakan dosis optimal yang dapat memberikan penurunan rasa nyeri terbesar, hal ini dibuktikan dengan hasil mean delta nyeri dengan angka tertinggi 4,14 yaitu pada P1. Selain pada P1, pada P2 juga terdapat penurunan intensitas nyeri dismenore primer setelah diberikan perlakuan berupa konsumsi kacang mente sebanyak 68 gram dengan hasil mean delta nyeri sebesar 2,71. Pada kelompok kontrol yang tidak diberikan perlakuan, mean delta nyerinya menunjukkan angka $-0,57$ yang artinya pada kelompok ini, responden cenderung mengalami intensitas nyeri dismenore yang meningkat. Mean delta nyeri tersebut menunjukkan bahwa semakin besar nilainya maka semakin besar pula dosis tersebut dapat memberikan efek berupa penurunan intenistas nyeri dismenore primer.

Pada uji post hoc yang telah dilakukan juga didapatkan hasil bahwa terdapat perbedaan bermakna dengan nilai signifikansi $p=0,000$ antara $P 1$ maupun P2 dengan kelompok kontrol. Hal ini berarti responden yang berada dalam P1 dan P2 mengalami perubahan intensitas nyeri dismenore primer setelah mengonsumsi kacang mente dengan dosis 82 gram kacang mente pada P1 dan 68 gram kacang mente pada P2. Akan tetapi, pada uji post hoc yang disajikan pada tabel 5,4 menunjukkan bahwa tidak ada perbedaan yang bermakna antara kelompok I dan kelompok II dengan nilai signifikansi $p=0,109$. $\mathrm{Hal}$ ini berarti dengan penambahan dosis dari dosis 68 gram pada P2 menjadi dosis eksperimental I sebesar 82 gram kurang memiliki perbedaan bermakna terhadap meningkatnya kemampuan untuk menurunkan intensitas nyeri dismenore primer pada responden.

Pada kelompok kontrol, sebanyak 1 responden (14,3\%) mengalami peningkatan nyeri dismenore primer dari derajat nyeri sedang menjadi derajat nyeri berat. Hal ini dapat disebakan karena penilaian derajat nyeri dismenore primer dengan menggunakan kuesioner berupa NRS (Numerical Rating Score) yang bersifat subjektif sehingga dapat mempengaruhi persepsi nyeri yang dirasakan oleh responden. Selain hal tersebut, menurut Hendrik (2006) menyebutkan bahwa dismenore primer ini dapat bertahan 24-36 jam 
dan intensitas nyeri beratnya dapat berlangsung pada 24 jam pertama. Sehingga dapat disimpulkan bahwa peningkatan nyeri yang dialami responden pada kelompok kontrol ini dapat disebabkan karena faktorfaktor diatas. ${ }^{23}$ Perubahan penurunan intensitas nyeri dismenore primer yang signifikan pada P1 dan P2 terjadi karena adanya kandungan magnesium yang terdapat dalam kacang mente dengan dosis magnesium sebesar $300 \mathrm{mg}$ magnesium dalam 68 gram kacang mente pada dosis P2 dan $360 \mathrm{mg}$ magnesium dalam 82 gram kacang mente pada dosis P1. Hasil dari penelitian ini sejalan dengan penelitian yang dilakukan oleh Wulandari dan Afriliana (2017), responden yang diberikan dark chocolate sebanyak 260 gram yang mengandung $300 \mathrm{mg}$ magnesium menunjukkan hasil yang signifikan dalam menurunkan intensitas nyeri dismenore primer. ${ }^{24}$ Gagua (2012) dalam penelitiannya menunjukkan bahwa pemberian magnesium pada responden dibandingkan dengan kelompok placebo memberikan hasil bahwa magnesium merupakan treatment yang efektif dan menjanjikan dalam menurunkan nyeri dismenore. Magnesium lebih efektif daripada placebo untuk meringankan nyeri pada penelitian yang dilakukan secara three small RCTs dan responden pada kelompok yang diberikan magnesium membutuhkan obat pereda nyeri yang lebih rendah dibandingkan dengan kelompok placebo. ${ }^{25}$ Menurut Dune (2002) magnesium dapat meredakan nyeri menstruasi, dengan pemberian magnesium sebagai dosis terapi yaitu sebesar $300 \mathrm{mg}$ magnesium. ${ }^{26}$ Penelitian lain yang dilakukan oleh
Grober et al (2015) menyatakan bahwa magnesium dengan sediaan magnesium pidolat $4,5 \mathrm{mg}$ yang diberikan sebanyak 3 kali/hari dari hari ke-7 sebelum menstruasi hingga hari ke-3 dimulainya menstruasi dapat menurunkan keparahan dismenore yang dirasakan oleh responden secara signifikan. ${ }^{27}$

\begin{tabular}{lc}
\multicolumn{3}{c}{ Magnesium memiliki efek } \\
langsung terhadap tekanan \\
pembuluh darah dan dapat
\end{tabular} mengatur masuknya kalsium ke dalam sel otot polos dan uterus, sehingga magnesium mempengaruhi kontraksi dan relaksasi dari otot polos uterus. Magnesium juga dapat menekan terjadinya inflamasi dengan menghambat terbentuknya prostaglandin. ${ }^{28}$ Dalam literature lain disebutkan peran magnesium dalam menurunkan kontraksi otot polos adalah sebagai antagonis kompetitif untuk mengontrol masuknya kalsium ke dalam sel. Mekanisme pencegahan eksitasi dan kontraksi otot polos adalah dengan mengatur uptake, binding, juga distribusi kalsium ke dalam sel. Magnesium juga mencegah terbukanya VGCC sebagai respon terhadap potensial aksi, sehingga influks kalsium tidak terjadi. ${ }^{29}$

Dengan menurunnya konsentrasi ion kalsium intrasel, maka ikatan kalsium-kalmodulin akan berkurang. Miosin kinase tidak teraktivasi sehingga tidak ada fosforilasi rantai ringan myosin. ${ }^{30}$ Sebaliknya, myosin light chain phosphatase (MLCP) akan teraktivasi. Enzim ini terletak dalam cairan sel otot polos uterus. Sistem kerjanya adalah menguraikan fosfat dari rantai ringan tersebut. Akibatnya, myosin tidak bisa 
melakukan interaksi cross-bridge dengan aktin sehingga kontraksi tidak terjadi. ${ }^{31}$ Fungsi lain dari magnesium adalah menurunkan pelepasan katekolamin yang menyebabkan kekuatan kontraksi miometrium berkurang, memperbaiki vaskularisasi uterus, dan mengurangi sensasi nyeri. ${ }^{32}$

$$
\text { Pada penelitian ini }
$$

menunjukkan hasil yang signifikan terkait penurunan intensitas nyeri dismenore primer pada responden yang mengonsumsi kacang mente. Hal ini dapat terjadi karena berdasarkan penelitian yang dilakukan oleh Yokubova (2012), beliau melakukan penelitian pada sekelompok wanita Uzbekistan berusia 13-17 tahun dengan dismenore primer menunjukkan penurunan kadar magnesium plasma yang seharusnya $0,7 \pm 0,2$ $\mathrm{mg} / \mathrm{mL}$ menjadi $0,5 \pm 0,2 \mathrm{mg} / \mathrm{mL}$ sedangkan kadar magnesium tetap normal $0,7 \pm 0,2 \quad \mathrm{mg} / \mathrm{mL}$ sampai $0,9 \pm 0,2 \mathrm{mg} / \mathrm{mL}$ pada wanita tanpa dismenore. ${ }^{33}$ Sehingga dengan pemberian kacang mente yang mengandung 300 dan 360 mg magnesium yang diberikan pada kelompok eksperimental I dan II maka dapat meningkatkan kadar magnesium plasma dan dapat menurunkan intensitas nyeri dismenore primer pada responden dalam kelompok eksperimental I dan II.

\section{SIMPULAN}

Secara umum dapat disimpulkan bahwa terdapat pengaruh konsumsi kacang mente terhadap perubahan intensitas nyeri dismenore primer dengan mengacu pada beberapa hasil berikut:

1. Intensitas nyeri sebelum diberikan perlakuan pada P1 dan
P2 adalah 100\% responden mengalami intensitas nyeri sedang dengan rata-rata intensitas nyeri sebesar 4,7 pada P1 dan 5,1 pada P2. Sedangkan intensitas nyeri sebelum diberikan perlakuan pada kelompok kontrol adalah 28,6\% responden mengalami nyeri ringan dan $71,4 \%$ responden mengalami nyeri sedang dengan rata-rata intensitas nyeri sebesar 4,3.

2. Setelah diberikan perlakuan, intensitas nyeri pada $\mathrm{P} 1$ adalah $71,4 \%$ responden tidak merasakan nyeri dan $28,6 \%$ responden mengalami nyeri ringan dengan rata-rata nyeri pada $\mathrm{P} 1$ post-tes adalah 0,6 . Pada P2, intensitas nyeri setelah diberikan perlakuan sebesar $85,7 \%$ responden tidak mengalami nyeri, dan $14,3 \%$ responden mengalami nyeri sedang dengan rata-rata intensitas nyeri pada P2 sebesar 2,4 . Sedangkan pada kelompok kontrol setelah diberikan intervensi intensitas nyeri sebesar 28,6\% responden mengalami nyeri ringan, $57,1 \%$ responden mengalami nyeri sedang, dan $14,3 \%$ responden mengalami nyeri berat dengan rata-rata intensitas nyeri responden pada kelompok kontrol sebesar 4,9.

3. Terdapat perbedaan bermakna konsumsi kacang mente terhadap penurubahan intensitas nyeri dismenore primer pada siswi SMAN 1 Lawang sebelum dan sesudah mengonsumsi kacang mente dengan hasil signifikansi $p=0,000$.

4. Perbedaan bermakna ditunjukkan antara P1 (kacang 
mente 82 gr) terhadap kelompok kontrol dengan nilai signifikasi $\mathrm{p}=$ 0,000 dan antara P2 (kacang mente $68 \mathrm{gr}$ ) terhadap kelompok kontrol dengan nilai signifikansi $\mathrm{p}=0,000$. Sedangkan tidak terdapat perbedaan yang bermakna antara P1 terhadap $\mathrm{P} 2$ dengan signifikansi $\mathrm{p}=0.109$. Dengan demikian dapat diartikan bahwa dengan penambahan dosis konsumsi kacang mente menjadi sebesar 82 gram tidak memberikan perbedaan bermakna terhadap penurunan intensitas nyeri dismenore primer pada siswi SMAN 1 Lawang.

\section{DAFTAR PUSTAKA}

1. Colin, C.M., \& Shushan, A. (2007). Complications of menstruation; abnormal uterine bleeding. In: Current Diagnosis \& Treatment Obstetrics \& Gynecology. $10^{\text {th }} \quad$ Edition. Chapter 35:572-3. USA. McGraw-Hill.

2. Chen CX, Kwekkeboom $\mathrm{KL}$ and Ward SE. Self-report pain and symptom measures for primary dysmenorrhoea: A critical review. European Journal of Pain. 2015; 19 (3): 377 -91.

3. Karim Anton, C., \& Michael R, R. 2013. Dysmenorrhea. Medscape refference.

4. Hsu CS, Yang JK, Yang LL. Effect of a dysmenorrheal Chinese medicinal prescription on uterus contractility in vitro. Phytother Res 2003;17:778-83.

5. Polat A, Celik H, Gurates B, et al. Prevalence of primary dysmenorrhea in young adult female university students. Arch Gynecol Obstet 2009;279:52732.
6. Zukri SM, Naing L, Hamzah TNT, Hussain NHN. Primary dysmenorrhea among medical and dental university students in Kelantan: prevalence and associated factors. IMJ. 2009;16:93-9

7. Loto OM, Adewumi TA, Adewuya AO. Prevalence and correlates of dysmenorrhe among Nigerian college women. Aust $N Z \mathrm{~J}$ Obstet Gynaecol 2008;48: 4424.

8. Dawood MY. Primary dysmenorrhea: Advances in pathogenesis and management. Obstet Gynecol 2006;108:428441.

9. Burke A, Smyth EM, FitzGerald GA. 2006. Analgesic-Antipyretic and Antiinflammatory Agents; Pharmacotherapy of Gout. In: Brunton L, Lazo J, Parker K, eds. Goodman \& Gilman's The Pharmacological Basis of Therapeutics, 11th ed. New York: McGraw-Hill Professional :671-716.

10. Proctor ML, Murphy PA, Pattison $\mathrm{HM}$, et al. Behavioural interventions for primary and secondary dysmenorrhoea. Cochrane Database Syst Rev 2007 Jul 18;(3):CD002248.

11. Devi, N. 2012. Gizi saat sindrom menstruasi. Jakarta : PT Bhuana Ilmu Populer Kelompok Gramedia.

12. Mary P. Guerrera., Stella Lucia Volpe., and Jun James Mao. Therapeutic Uses of magnesium. American Family Physician. 2009, 80 (2):157-162.

13. Almatsier, Sunita. 2002. Prinsip IImu Gizi. Jakarta: PT Gramedia.

14. Direktorat Jendral Perkebunan. 2015. Statistik Perkebunan Indonesia tahun 2013-2015: 
Jambu Mente. Jakarta: Direktorat Jendral Perkebunan.

15. Gagua , T. Primary dismenorrhea-Leading Problem of Adolescent Gynecology (Review). Georgian Medical News, 2012, 6 (207): 7-13.

16. Mufaridah Fifin dan Sumaryani Sri. Pengaruh Pemberian Tebu Ireng (Saccharum officinarum) terhadap Tingkat Dismenore Pada Siswi Madrasah Aliyah Negeri Pakem Sleman Yogyakarta. 2014: 1-11

17. Baziad. 2003. Endokrinologi Ginekologi. Jakarta: Media Auskulapius

18. Rude RK. Magnesium. In: Ross AC, Caballero B, Cousins RJ, Tucker KL, Ziegler TR, eds. Modern Nutrition in Health and Disease. 11th ed. Baltimore, Mass: Lippincott Williams \& Wilkins; 2012:159-75.

19. Mirabi Parvaneh., Dolatian Mahrokh., Mojab Faraze., and Majd Hamid. Effect of Valerian on The Severity and Systemic Manifestations of Dysmenorrhea. Gynecology \& Obstetrics, 2011, 115 (3): 285-288.

20. Ortiz, Mario. Primary Dismenorrhea Among Mexican University Students: Prevalence, Impact, and Tratment. Europan Journal of Obstetrics \& Gynecology and Reproductive Biology: Elsevier, 2010, 152: 7377.

21. Nahid Khodakrami., Fariborz Moatar., Ataolah Ghahiri., and Solokian Shahdan. The Effect of an Iranian Herbal Drug on Primary Dysmenorrhea: A Clinical Controlled trial. Journal of Midwefery and Women's Health: Elsevier. 2009, 54 (5): 401-404.
22. Tamsuri, A. 2007. Konsep dan penatalaksanaan nyeri. Jakarta: EGC.

23. Hendrik. 2006. Problema haid: tinjauan syariat islam dan medis. Solo: PT Tiga Serangkai Pustaka Mandiri.

24. Wulandari Siswi and Afriliana, Fitra Dwi. The Effect of Consumption dark Chocolate Against Primary Dismenore Pain For Girl Teenager at Kediri 5 High School. Indian Journal of Medical Reasearch and Pharmaceutical Science, 2017, 4 (2): 17-24.

25. Gagua Tinatin., T Besarion., and Gagua David. Primary dismenorrhea: Prevalence in Adolescent Population of Tbilisi, Georgia and Risk Factors. Journal Turkish-German Gynecol Association, 2012, 13: 162-168.

26. Dunne, Lavon. 2002. Nutrition Almanac: Fifth Edition. New York: McGraw-Hill.

27. Gröber U, Schmidt J, Kisters K. Magnesium in prevention and therapy. Nutrients. 2015;7:8199226.

28. Suwindere, W., Tih, F., \& Nurazizah, E. 2015. Konsumsi Cokelat Hitam Mengurangi Gejala Subyektif Perempuan Penderita Sindroma Premenstrual Usia 18-22 Tahun. Journal of Medicines and Health, vol. 1 no. 1.

29.Blackburn, Susan. 2014. Parturition and Uterine Physiology, In: Maternal, Fetal, and Neonatal Physiology : A Clininal Perspective, 4th Edition, Elvesier Health Sciences, pp. 135-136.

30. Guyton, Arthur C, John E. Hall, 2012, Kontraksi dan Eksitasi Otot Polos dalam : Buku Ajar 
Fisiologi Kedokteran, Edisi 11, Penerbit Buku Kedokteran EGC, Jakarta, HIm. 95-103.

31. Otaibi, M.A. 2014. The physiological mechanism of uterine contraction with emphasis on calcium ion, Research Pub, Jun, VOL.1 NO.2, pp. 2373-1168.

32. Haft WA, Vallejo MC. The changing role of magnesium in obstetric practice. Anesthesiol Clin. 2013;31(3):517-28.

33. Yokubova, Oltinoy. Juvenile Dysmenorrhea Associated with Hypomagnesemia and Connective Tissue Dysplasia. Medical and Health Science Journal, 2012, 11: 85-88. 